\title{
Revival of a Research Association
}

\author{
The British Food Manufacturing Industries Research Association \\ almost collapsed last year. It now seems well on the way to \\ recovery.
}

\begin{abstract}
THE British Food Manufacturing Industries Research Association at Leatherhead, which at one stage in 1966 looked as though it might possibly go out of business altogether (see Nature, 211,$561 ; 1966$ ), seems to have recovered from the period of internal disputes and dissensions, and lack of financial support from the industry, which had paralysed it. The industry has learnt something of its lesson, and with the appointment of Dr A. W. Holmes, who succeeded Dr C. L. Cutting as director at the beginning of 1967, and a new secretary it has rallied round the association and put the laboratory back on its feet. It has provided adequate, if not generous, funds, and agreed to changes in organization which at least make the director master in his own house. No doubt the industry's fear of the stigma of having its research association collapse entirely has had as much to do with this as the recognition that, properly run, the association can, in fact, provide the industry with research facilities on the cheap. The food manufacturing industry still has a conservative hard core which simply does not realize the importance of research and regards the association as a charity rather than anything else.
\end{abstract}

When Dr Holmes arrived at the beginning of 1967, armed with the report of a firm of management consultants called in by the association to help sort out its problems, morale could hardly have been lower. Staff had been leaving, and not only was no one certain what relevance many of the research projects then in hand had to the industry's needs but there was hardly any equipment with which to work. Betweeen 1945 and 1966 , only $£ 50,000$ had been spent on new apparatus and budgets had been so tight that the predicted working surplus for the year 1967 was a trivial $£ 600$. An immediate appeal was made to raise $£ 70,000$ for equipment-spectrophotometers, an electron microscope and the like--and with the help of a supplementary grant from the Ministry of Technology to match the industry's contributions, more than $\mathfrak{£} 68,000$ has been collected, $£ 37,000$ from the industry and $£ 31,000$ from the Government.

But, as many other laboratories have learnt, although useful research cannot be done without proper equipment, buying fine equipment is no guarantee of successful research. Recent history had proved the association needed a change in research policy and organization above all else. The new policy is to try to run the association as a business; to soll the industry the research information that it needs and simultaneously to convince it of the need for rescarch. Of course, to achieve this the Byzantine organization of the association has been scrapped. In place of twelve panels drawn from the industry, which previously allocated all the funds, the director and six panels allocate the industry's contributions. The Government's contributions are controlled by a research committee of industrial representatives and senior staff of the laboratory and profits from contract work are being used to finance new buildings.

The statistics in the annual report of the association for 1967 testify to the success of the new regime. The staff of the laboratories has increased from eightythree to more than one hundred. The association had a surplus of more than $£ I 4,000$ instead of a deficit of about $£ 16,000$ in 1966 , the total income has risen from $£ 184,000$ to very nearly $£ 250,000$ and the total grant earning income, in effect the industry's contributions which qualify for a Ministry of Technology grant, will this year exceed $£ 135,000$ and the upper grant earning limit set by the Ministry. The food manufacturers have no cause to rest on their laurels, however. It is hard to believe that an industry, which has an annual turnover of about $£ 700$ million, takes its research association seriously when it contributes only $£ 135,000$ annually. The industry could obviously support an association three or four times the present size.

And the association now has more to show for its new policies than just an increased income. It has recently received a grant of $£ 20,000$ from the Nuffield Foundation for a three year study of carcinogens and other undesirable substances produced during meat curing by the nitrates and nitrites that are used. The association hopes to cajole the industry into providing as further $£ 80,000$ for this work-so far it has received $£ 15,000$. There is increasing evidence that the interaction between nitrites and amines in meat can produce carcinogens such as nitrosamine (see Lancet, May 18, 1071; 1968). Clearly, although there may be no cause for everyone in a moment of panic to forgo bacon or pickled meat, the industry should know a great deal more about the chemistry of curing than it does. And its association, armed with the Nuffield grant and the experience gained from contract work for the US Department of Agriculture, is the best place for this research.

On its own initiative the association has also made in the last year what may prove to be an important, but embarrassing, innovation in chocolate manufacture. The association has developed a new process which, it claims, makes chocolate in hours instead of days. Obviously if it proves possible to scale up the new method to commercial levels, there should be rreat savings in the chocolate and cocoa industry. This prospect, of course, presents the association with a ticklish problem. If the process is a commercial success, should it be offered free to members or should the association take out a patcnt and sell licences, perhaps offering member companies the most favourable terms? Although there are precedents in other associations for both alternatives, the betting is that the association will take out a patent. The member companies at first sight may feel they have a right to exploit the process freely, but why should one branch of the industry benefit uniquely from research which has in effect been supported by the whole industry? If the process is a success, the future finance of the laboratory may be assured; and even if all this turns out to be wishful thinking, there remains the consolation that the idea is symptomatic of the improved climate at Loatherhead. 